\title{
The Determination of the Degree of Eutrophication of the Lakes on the Romanian Seaside of the Black Sea
}

\author{
S. Godeanu, L.D. Galatchi
}

Universitatea Ovidius Constanta, 10 General Grigore Ipatescu str. 024058, Bucharest, Romania. E-mail stoica@bucura.ro

\begin{abstract}
This paper contains a compilation of the average values of 24 geographical, physical, chemical, biological and productivity parameters collected and processed during 12 years of research on 9 freshwaters and salmastricol lakes situated on the Romanian seaside of the Black Sea. The paper emphasizes the discussion of those parameters indicating the current degree of eutrophication of these lakes. It shows that the lakes situated in the southern part of the Romanian seaside (Limanu, Valea Arsa and Hagieni) are the least affected by the process of eutrophication; they are followed by the northern lakes (Razim and Sinoie) which are supplied with the waters of the Danube river, after these have been filtered in the floodable areas of the Danube Delta. The process of eutrophication is found to be stronger in the waters close to the agricultural areas and the urban localities from the Romanian seaside of the Black Sea.
\end{abstract}

Keywords: lakes, eutrophication, primary production, water quality

\section{Introduction}

The economic development of Dobrudja, particularly of its sea coast area (Fig. 1), during the last 4-5 decades has had a great impact on the natural terrestrial and aquatic environment. As there has been no concern regarding the protection of the environment, this impact has appeared with all the intensity, which has lead to the occurrence of degradation processes which, according to their intensity, have altered the environment in different ways.

Agricultural works in the last 4 decades have lead to the fallowing of a large part of the old Dobrudjan steppe, which has increased the erosion process. This has caused an intensification of the processes of accumulation of the material into the lakes, washed away from the bottoms of the valleys by the rainfall, and if there was an aquatic basin in such a valley, it has sped up the silting process. To this, the administration of chemical fertilizers was added, which, washed down by the rain from the slopes, has led to an intensification of the anthropic eutrophication process of the respective basin. Such a situation can be seen in the cases of the Razim, Tasaul (Navodari) and Techirghiol lakes (Fig. 1). Another form of alteration of the aquatic basins is represented by the establishment of the pisciculture system, which besides the creation of dams and the partitioning of the lakes, has resulted in the so- called "fattening" of the basin. This process consists in throwing into the water substantial quantities of manure or nutrients. This is how the eutrophication process is deliberately accelerated by man with a view to increasing the fish production. Such a situation can be seen at the Tatlageac Lake.

A third form of accelerating the eutrophication process is achieved by the input of liquid or solid wastes from the localities situated in the close vicinity of the aquatic basins. In human settlements, people throw various wastes like garbage, manure etc. on the shores of the lakes. The rain waters wash down such waste, which reach the lake, causing the loading of the waters with organic matters, carbohydrates, oils, detergents, household chemicals etc. If there are factories in the riparian localities, their liquide wastes are also disposed off in the nearby lake, or in one of its tributaries. Such situations occurred at Corbu (Gargalac), Tasaul (Navodari) and Mamaia (Siutghiol). An extreme case is represented by the Tabacarie Lake, where part of the drain waters brought from the northern part of the city of Constanta have been discharged for over three decades. As a result, this is the most degraded lake due to the impacts of anthropic pollution on the Romanian seacoast of the Black Sea. 

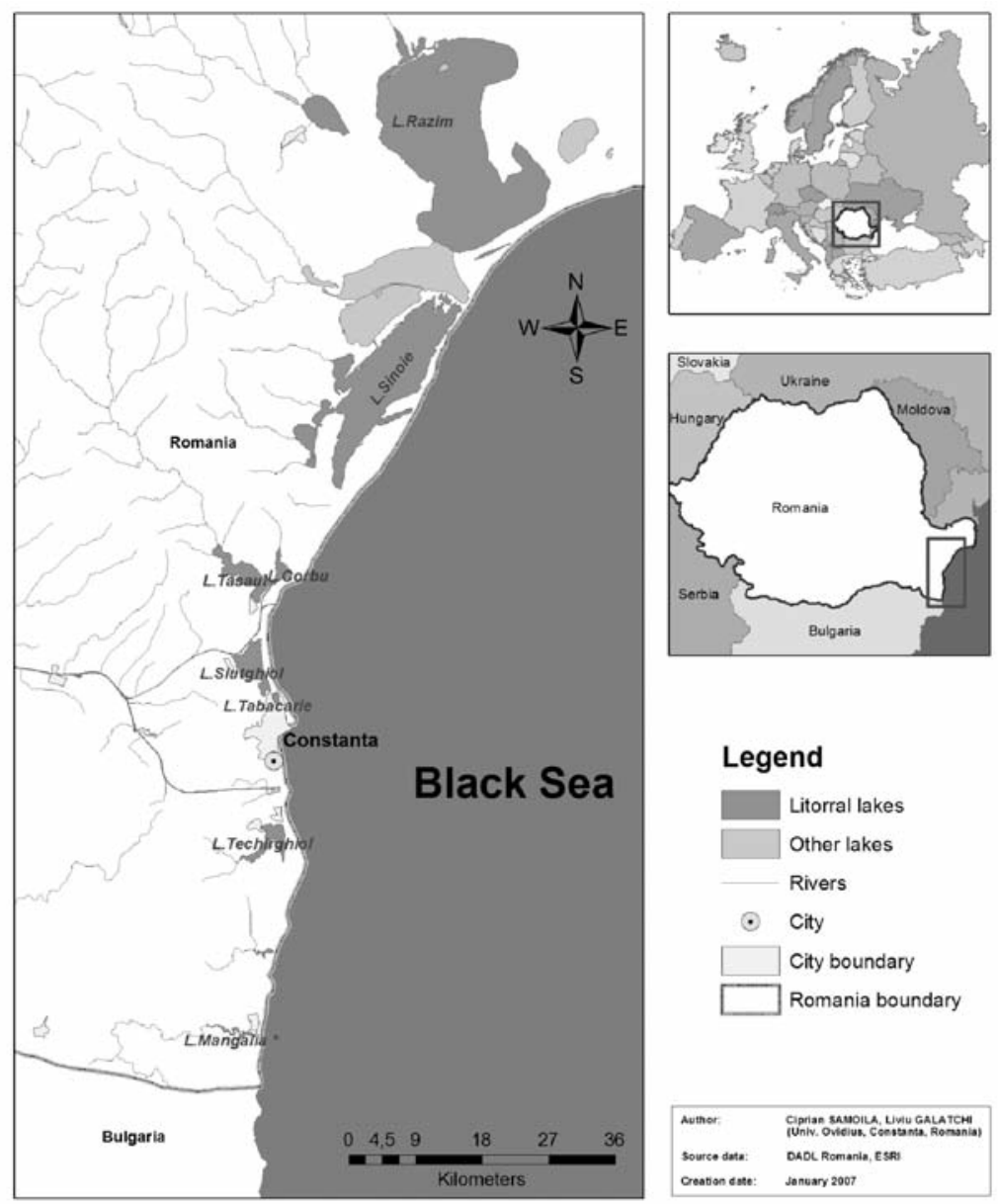

Fig. 1. Map of the Black-Sea romanian seashore.

\section{Material and methods}

During the last two decades, research was carried out concerning the lakes existing along the Romanian sea coast of the Black Sea. They aimed to show some aspects related to the physical and chemical characteristics of the sea coast lakes as well as some of their biological and limnological characteristics. This research went on during 12 years (monthly, representing all the seasons, between 1993-2005), and the data were collected from Razim, Sinoie, Corbu (Gargalac), Tasaul (Navodari), Mamaia (Siutghiol), Tabacarie, Limanu and Hagieni lakes (Fig. 1). From time to time, the Agigea, Techirghiol, Tatlageac, Neptun and Mangalia lakes were also investigated. The samples have been taken near the shore and in the middle of each lake, $10-25 \mathrm{~cm}$ below the water surface. Minimum, average, maximum values have been recorded. The physical and chemical tests were performed both on site and in the laboratory, using the methods recommended by the Romanian standards. The measurements of the primary production were performed on site using the Winkler bottles method, and in the laboratory using the method of the measurement of the quantities of chlorophyll "a" in the mass of water. To determine the phytoplankton, samples of 1 liter of water were collected, in which, after treatment with IIK, formalin fixing, a 30-day decantation and the concentration of the material, the components were identified quantitatively and qualitatively. To determine the zooplankton, water was collected using a device of the Patalas type and filtered through plankton net with 40 micrimeter diameter. The quantitative and qualitative determinations were performed with a Kolkwitz chamber in the laboratory. 


\section{Results and discussion}

Table 1 presents the compilation of the results of the tests performed and includes only the minimum, mean and maximum values of the tests performed for every lake, for 20 parameters. Even at first sight it is obvious that there is a wide variety of data and this fact has led to the conclusion that, based on its origin, evolution and degree of deterioration caused by certain human impacts, every lake has its particular situation which can be compared to that of the others only insofar as to achieve their global characterization. This is why the collected data were considered on the overall, the collected data allowing only the drawing of a series of general conclusions.

The analysis of the chemical consumption of oxygen (COD) shows a very wide variation of the values of this parameter, both from one lake to the other, and from one sample taking to another. The maximum values were recorded in the Sinoe Lake, followed by those of the Tabacarie Lake. The minimum values were found in the lakes situated in the southern part of the Romanian sea coast, at Hagieni and Valea Arsa (Fig. 2). We estimate that the extremely high values recorded in the Sinoe Lake are due to the presence of the humic substances carried over by the water currents at the surface of the benthos and not by excessive pollution. This is confirmed by the values of the biochemical consumption of oxygen (BOD), which are not higher than the values recorded in the other lakes which are not that affected (Fig. 3). The situation of the Tabacarie Lake is, obviously, different, this being the most polluted lake on the Romanian sea coast of the Black Sea.

It can also be noticed that the COD values of the lakes north of Constanta are higher than those of the lakes in the southern part of the Romanian sea coast (Limanu, Hagieni, Valea Arsa), which are less damaged by the human impact (the lakes in the northern part of the Romanian sea coast have mean COD values of 6.8-7.6 $\mathrm{mg} \mathrm{O}_{2} / \mathrm{dmc}$, whereas those in the southern part of the Romanian sea coast have mean values of only 3.5-4.3 $\mathrm{mg} \mathrm{O}_{2} / \mathrm{dmc}$ ).

The values of BOD vary within narrower limits (4.6-6.7 $\mathrm{mg} \mathrm{O}_{2} / \mathrm{dmc}$ ), except for the Razim Lake, which has the mean value of BOD of $3.5 \mathrm{mg} \mathrm{O} / \mathrm{dmc}$ (Fig.3). We estimate that this value is the result of the way in which the water from the Danube feeding the lake is filtered by the areas of reed through which the water passes to reach the lake and which retain a large part of the biodegradable organic substances. The Corbu and Siutghiol lakes have relative low values of

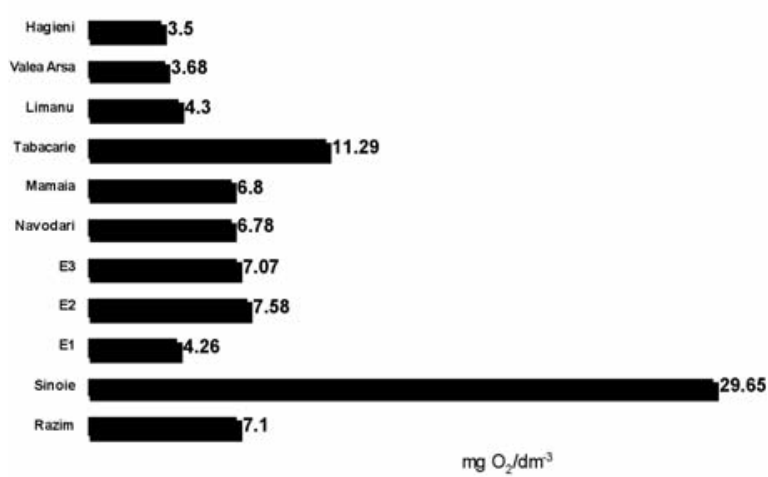

Fig. 2. Medium values of the oxygen chemical demand (COD) in the Romanian coastal lakes.

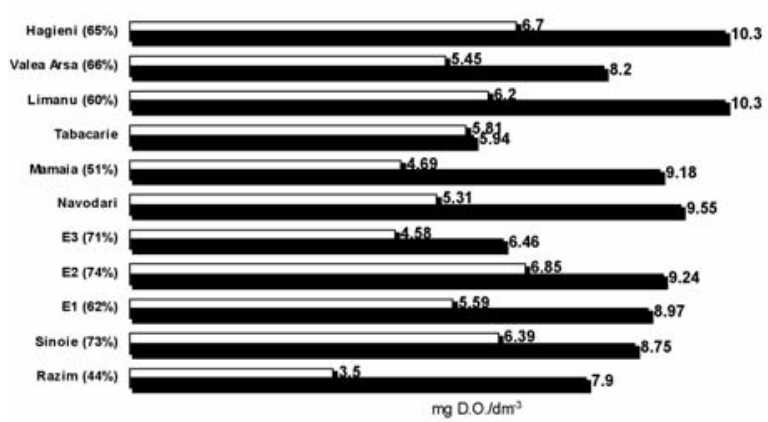

Fig. 3. Mean of biochemical oxygen consumption (B.O.C. ${ }^{\text {) }}$ ) and the dissolved oxygen (D.O.) in the Romanian coastal lakes.

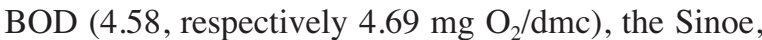
and Hagieni or basin E2 lakes have the maximum values of $\operatorname{BOD}(6.39,6.7$, respectively $6.85 \mathrm{mg} \mathrm{O} / 2 \mathrm{dmc})$.

The mean values of the dissolved oxygen show that all the lakes, except for the Tabacarie Lake, are well oxygenated in the summer (they have mean values of 7.9-10.3 $\mathrm{mg} \mathrm{O}_{2} / \mathrm{dmc}$ ) (Fig.3). In the Tabacarie Lake, where the mean value of the dissolved oxygen is $5.94 \mathrm{mg} \mathrm{O}_{2} / \mathrm{dmc}$ and in the $\mathrm{E} 3$ stock pond in the Corbu Lake where the mean value of the dissolved oxygen is 6.46 the $\mathrm{mg} \mathrm{O}_{2} / \mathrm{dmc}$, the load of biodegradable organic substances makes the intensity of the consumption of dissolved oxygen determine its presence in somewhat lower concentrations.

The measurements carried out to determine the thickness of the euphotic layer were especially performed because this is where the main biological processes, particularly the primary production of phytoplankton, is achieved. So, the thickness of this layer has a decisive influence on the primary production of 


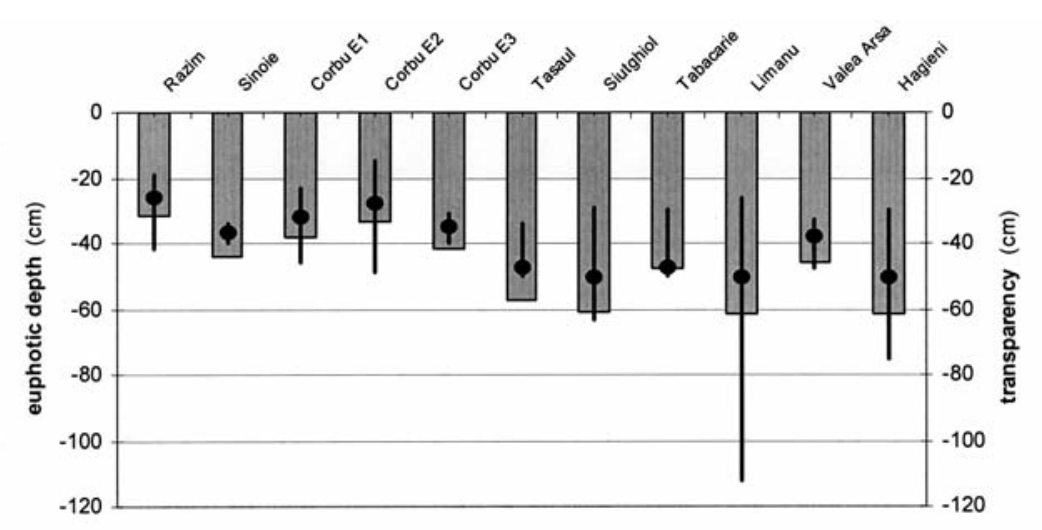

Fig. 4. Medium transparency and the euphotic depth of the Romanian coastal lakes.

the lakes and, implicitly, on the fish productivity. The thickness of the euphotic layer is relatively uniform, $32-61 \mathrm{~cm}$ on the average, which indicates that the productivity of these lakes obviously depends on their size and not on their absolute depth (as the basin morphometry has an indirect influence on the primary productivity). The minimum values of the euphotic layer are found in the Razim, Sinoe and Corbu lakes; the mean values are in the Tabacarie and Valea Arsa lakes, and the maximum values are in the Tasaul, Siutghiol, Limanu and Hagieni lakes (Fig. 4).

The mean transparency in the sea coast lakes varies between 19 and $42 \mathrm{~cm}$ in the Razim Lake and $21-112 \mathrm{~cm}$ in the Limanu Lake. On the overall, the Razim, Sinoe and Corbu lakes (all of them strongly exposed to dominant winds) have transparencies under $40 \mathrm{~cm}$ (usually $26-37 \mathrm{~cm}$ ), and the others have mean values of $38-51 \mathrm{~cm}$. The limits between the minimum and the maximum transparency vary little (except for the Limanu Lake, followed by the Hagieni and Siutghiol lakes - Fig. 4).

It should be noticed that there is a consistency between the values of the mean transparency and those of the thickness of the euphotic layer, which is slightly higher than the first one.

The investigation of the mean values of the number of species of phytoplankton organisms (Table 1) shows that this varies within very wide limits, from 12 species in the E3 stock pond in the Corbu Lake, up to 119 species in the Razeim Lake. The aquatic basins most affected by the high input of exogenous organic substances have a lower number of species (there are 52 species in the Tabacarie Lake and 35 species in the E1 stock pond in the Corbu Lake), whereas the cleaner fish basins have a greater biodiversity (119 phytoplankton species were identified in the Razim Lake, 81 species in the Hagieni and Limanu lakes, 105 species in the Siutghiol Lake). It should also be noticed that if a stock pond is larger, its biodiversity is higher (the biodiversity of the phytoplankton organisms in the Razim, Sinoe, Siutghiol lakes should be not compared with that in the Tabacarie Lake or in the stock ponds basins in the Corbu Lake).

The biomass of the phytoplankton (i.e. that of the primary producers in the water mass/ euphotic layer) is relatively similar in point of mean values between the lakes (Fig. 5), fluctuating between $28.56 \mathrm{~g} / \mathrm{mc}$ in the Mamaia Lake and $106.12 \mathrm{~g} / \mathrm{mc}$ in the Tabacarie Lake. As against the overall mean value of $53.69 \mathrm{~g} / \mathrm{mc}$, the Sinoe, E1 and E3 in Corbu, Siutghiol, Limanu and Hagieni lakes are below this mean value, whereas the Razim, E2 in Corbu, Tasaul, Tabacarie and Valea Arsa lakes are above the mean value. It should be noticed that the Tasaul Lake has the highest absolute values, followed by the Razim and Tabacarie lakes. The minimum absolute values are recorded in the Sinoe and Hagieni lakes, which we consider to be the cleanest lakes on the Romanian coast of the Black Sea (Table 1).

The values of chlorophyll "a" (Table 1) are extremely unequal as they depend on the group of phytoplankton organisms (compare the quantity of chlorophyll "a" found in the same quantity of biomass of diatoms or peridinea with that from the green algae) and the total biomass of the phytoplankton organisms at the time of the sampling. The minimum values are encountered in the lakes in the southern part of the sea coast, the maximum ones in the northern lakes (Razim, Tabacarie, and E1 - Corbu). Since chlorophyll "a" is 


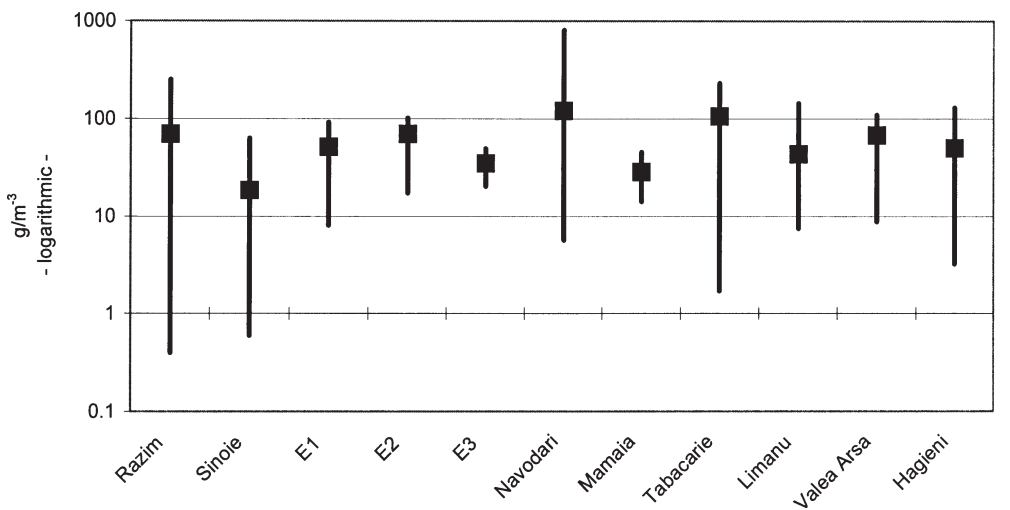

Fig. 5. Photosynthesizing plankton primary producers' biomass dynamics in the Romanian coastal lakes.

the main producer of organic carbon, we attempted to see whether there was any correlation between these 2 parameters (Fig. 7). We found that indeed there was a linear correlation. Moreover, we noticed that most of the lakes were grouped in the lower part of the value of the correlation, a mean value was recorded in the Tabacarie Lake, whereas the maximum value, very far from the others, was found in the others, as Razim Lake. If in the case of the Tabacarie Lake the explanation lies in the very high degree of eutrophication it has at present, in the case of the Razim Lake there is no such explanation.

When attempting to correlate the mean values of the concentration of chlorophyll "a" with the mean annual biomass of the phytoplankton (Fig.6), we noticed that this is less strict in comparison with that seen between chlorophyll "a" and organic carbon, the deviations from the mean value being, obviously, bigger. Nevertheless, in this case as well, most of the lakes have minimum values, although they are more spread out (the non-correlation is most obvious in the case of the Tasaul and Tabacarie lakes).

In the sea coast lakes, the number of taxons of the zooplankton organisms is relatively reduced, which means there is not a great biodiversity as a result of the instability of the ecosystem, caused by the pollution. It varies between 12 (in the Hagieni Lake) and 44 (in the Navodari Lake) (Table 1).

The green biomass of the zooplankton is much reduced in the E3 - Corbu Lake $(7.21 \mathrm{mg} / \mathrm{mc})$, the maximum values being recorded in the Tabacarie Lake $(9028.2 \mathrm{~g} / \mathrm{mc})$. In the other lakes the mean biomass is around 300-600 g/mc. The Valea Arsa, Hagieni and Corbu E3 lakes have values below $100 \mathrm{~g} / \mathrm{mc}$.

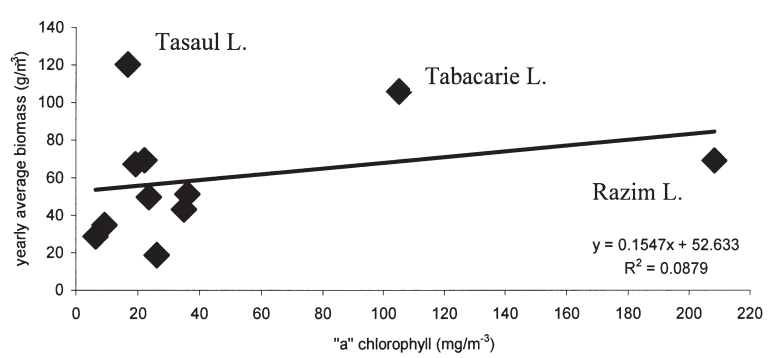

Fig. 6. Chlorophyll $a$ concentration correlated with the yearly average biomass of the photosynthesizing plankton primary producers in the Romanian coastal lakes.

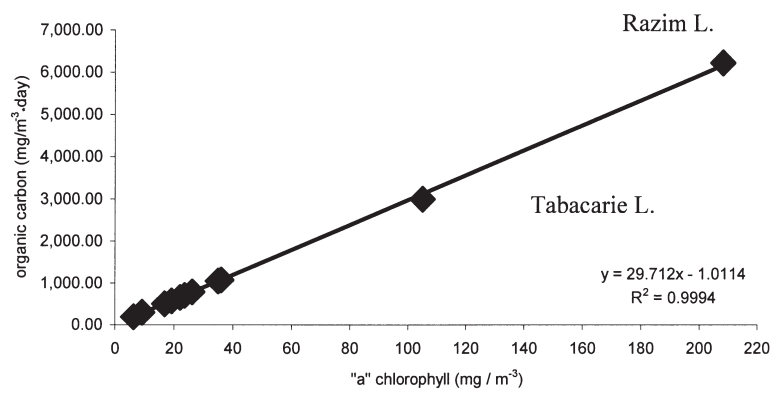

Fig. 7. Correlation between chlorophyll "a" values and total organic carbon in the Romanian coastal lakes. 
Table 1. Main physical, chemical and biological parameters of the Romanian coastal lakes. Mean values in bold.

\begin{tabular}{|c|c|c|c|c|c|c|c|c|c|c|c|}
\hline \multirow[b]{2}{*}{ Parameters } & \multirow[b]{2}{*}{ Razim } & \multirow[b]{2}{*}{ Sinoie } & \multicolumn{3}{|c|}{ Corbu } & \multirow[b]{2}{*}{ Tasaul } & \multirow[b]{2}{*}{ Siutghiol } & \multirow[b]{2}{*}{ Tabacarie } & \multicolumn{3}{|c|}{ Mangalia } \\
\hline & & & E1 & E2 & E3 & & & & Limanu & $\begin{array}{c}\text { Valea } \\
\text { Arsa Pond }\end{array}$ & Hagieni \\
\hline Surface (hectares) & 41500 & 17150 & 95 & 400 & 15 & 2035 & 1760 & 98.5 & - & - & 52 \\
\hline Depth (meters) & 1.90 & 1.25 & 1.15 & 1.30 & 0.80 & 2.43 & 4.65 & 2.15 & - & & 1.10 \\
\hline $\begin{array}{l}\text { Volume } \\
\text { (millions of } \mathrm{m}^{3} \text { ) }\end{array}$ & 788.50 & 214.37 & 1.10 & 5.20 & 0.12 & 49.45 & 81.84 & 2.11 & - & - & 0.60 \\
\hline $\begin{array}{l}\text { Transparence } \\
\text { (centimeters) }\end{array}$ & $\begin{array}{l}19 \\
26 \\
42 \\
\end{array}$ & $\begin{array}{l}34 \\
37 \\
40 \\
\end{array}$ & $\begin{array}{l}23 \\
32 \\
46 \\
\end{array}$ & $\begin{array}{l}15 \\
28 \\
49 \\
\end{array}$ & $\begin{array}{l}31 \\
35 \\
40 \\
\end{array}$ & $\begin{array}{l}34 \\
48 \\
50 \\
\end{array}$ & $\begin{array}{l}29 \\
51 \\
63 \\
\end{array}$ & $\begin{array}{l}30 \\
40 \\
50 \\
\end{array}$ & $\begin{array}{c}26 \\
51 \\
112 \\
\end{array}$ & $\begin{array}{l}33 \\
38 \\
48 \\
\end{array}$ & $\begin{array}{l}30 \\
51 \\
75 \\
\end{array}$ \\
\hline $\begin{array}{l}\text { Euphotic depth } \\
\text { (centimeters) }\end{array}$ & 31.39 & 44.46 & 38.40 & 33.60 & 42 & 57.60 & 60.74 & 48 & 61.20 & 45.96 & 61.20 \\
\hline $\begin{array}{l}\text { Euphotic volume } \\
\left(\mathrm{m}^{3}\right)\end{array}$ & $\begin{array}{c}130.26 \\
\text { mil } \\
16.52 \% \\
3139 / \mathrm{ha} \\
\end{array}$ & $\begin{array}{c}76.24 \\
\text { mil } \\
35.56 \% \\
4446 / \mathrm{ha} \\
\end{array}$ & $\begin{array}{c}0.3618 \\
\text { mil } \\
32.80 \% \\
3800 / \mathrm{ha} \\
\end{array}$ & $\begin{array}{c}1.344 \\
\text { mil } \\
25.84 \% \\
3360 / \mathrm{ha} \\
\end{array}$ & $\begin{array}{c}0.0525 \\
\text { mil } \\
43.75 \% \\
4200 / \mathrm{ha} \\
\end{array}$ & $\begin{array}{c}11.72 \text { mil } \\
11.72 \% \\
5760 / \mathrm{ha}\end{array}$ & $\begin{array}{c}10.69 \mathrm{mil} \\
13 \% \\
6074 / \mathrm{ha}\end{array}$ & $\begin{array}{c}0.4728 \mathrm{mil} \\
22.40 \% \\
4800 / \mathrm{ha}\end{array}$ & 6120/ha & 4596/ha & $\begin{array}{c}0.318 \mathrm{mil} \\
53 \% \\
6120 / \mathrm{ha}\end{array}$ \\
\hline$\sum \mathrm{N}\left(\mu \mathrm{g} \cdot \mathrm{dm}^{-3}\right)$ & $\begin{array}{c}38.80 \\
\mathbf{3 5 8 . 5 3} \\
1371.30 \\
\end{array}$ & $\begin{array}{c}78.56 \\
120.60 \\
168.50 \\
\end{array}$ & $\begin{array}{c}33.34 \\
1223.49 \\
1901.70 \\
\end{array}$ & $\begin{array}{c}50.51 \\
\mathbf{4 8 5 . 7 7} \\
1179.45 \\
\end{array}$ & $\begin{array}{c}76.78 \\
189.64 \\
269.30 \\
\end{array}$ & $\begin{array}{l}120.70 \\
417.02 \\
958.17 \\
\end{array}$ & $\begin{array}{c}83.74 \\
129.64 \\
182.62 \\
\end{array}$ & $\begin{array}{l}2521.10 \\
3499.00 \\
4513.80 \\
\end{array}$ & $\begin{array}{c}592.30 \\
\mathbf{9 2 5 . 9 0} \\
1354.50\end{array}$ & $\begin{array}{c}585.40 \\
1057.30 \\
1266.80\end{array}$ & $\begin{array}{l}1143.50 \\
1188.60 \\
1233.20\end{array}$ \\
\hline $\mathrm{P}\left(\mu \mathrm{g} \cdot \mathrm{dm}^{-3}\right)$ & $\begin{array}{c}1.20 \\
149.11 \\
714.00 \\
\end{array}$ & $\begin{array}{c}7.36 \\
14.60 \\
26.76 \\
\end{array}$ & $\begin{array}{c}11.96 \\
\mathbf{2 8 . 2 6} \\
143.50 \\
\end{array}$ & $\begin{array}{c}8.02 \\
28.26 \\
73.22 \\
\end{array}$ & $\begin{array}{c}8.75 \\
60.62 \\
120.40 \\
\end{array}$ & $\begin{array}{c}41.22 \\
144.21 \\
264.22 \\
\end{array}$ & $\begin{array}{c}40.68 \\
75.03 \\
140.54 \\
\end{array}$ & $\begin{array}{c}675.00 \\
\mathbf{1 2 4 9 . 8 0} \\
1792.60 \\
\end{array}$ & $\begin{array}{c}9.70 \\
14.50 \\
26.20 \\
\end{array}$ & $\begin{array}{l}10.50 \\
14.05 \\
17.20 \\
\end{array}$ & $\begin{array}{l}11.40 \\
19.90 \\
28.40\end{array}$ \\
\hline$\Sigma N / P$ & 2.40 & 8.26 & 43.29 & 17.18 & 3.12 & 2.89 & 1.72 & 2.79 & 63.85 & 75.25 & 59.72 \\
\hline Salinity $(\%)$ & $\begin{array}{l}0.50 \\
0.61 \\
0.80\end{array}$ & $\begin{array}{l}2.35 \\
3.99 \\
5.88\end{array}$ & $\begin{array}{l}0.45 \\
\mathbf{0 . 6 8} \\
1.70\end{array}$ & $\begin{array}{l}1.05 \\
1.83 \\
2.41\end{array}$ & $\begin{array}{l}1.69 \\
2.24 \\
3.28 \\
\end{array}$ & $\begin{array}{l}0.80 \\
0.97 \\
1.09\end{array}$ & $\begin{array}{l}1.01 \\
1.24 \\
1.42 \\
\end{array}$ & $\begin{array}{l}0.19 \\
0.25 \\
0.31 \\
\end{array}$ & $\begin{array}{l}0.27 \\
0.35 \\
0.71\end{array}$ & $\begin{array}{l}0.32 \\
0.35 \\
0.37\end{array}$ & $\begin{array}{l}077 \\
0.82 \\
0.89\end{array}$ \\
\hline Temperature $\left({ }^{\circ} \mathrm{C}\right)$ & 11.40 & 14.28 & 12.37 & 11.49 & 12.43 & 12.25 & 12.02 & 14.03 & 11.60 & 12.80 & 11.20 \\
\hline $\mathrm{pH}$ & $\begin{array}{l}8.00 \\
8.36 \\
8.80\end{array}$ & $\begin{array}{l}8.25 \\
8.53 \\
8.80 \\
\end{array}$ & $\begin{array}{l}8.27 \\
8.97 \\
9.34\end{array}$ & $\begin{array}{l}8.24 \\
8.63 \\
9.10 \\
\end{array}$ & $\begin{array}{l}8.60 \\
8.70 \\
8.80\end{array}$ & $\begin{array}{l}8.37 \\
8.71 \\
8.80 \\
\end{array}$ & $\begin{array}{l}7.90 \\
8.71 \\
9.20\end{array}$ & $\begin{array}{l}7.80 \\
8.30 \\
8.80\end{array}$ & $\begin{array}{l}8.10 \\
8.20 \\
8.40\end{array}$ & $\begin{array}{l}8.20 \\
8.21 \\
8.30\end{array}$ & $\begin{array}{l}8.20 \\
8.21 \\
8.30\end{array}$ \\
\hline $\begin{array}{l}\text { Dissolved oxygen } \\
\text { DO }\left(\mathrm{mg} \mathrm{O}_{2} \cdot \mathrm{dm}^{-3}\right)\end{array}$ & $\begin{array}{c}2.80 \\
7.90 \\
11.70\end{array}$ & $\begin{array}{l}7.42 \\
8.75 \\
9.44\end{array}$ & $\begin{array}{c}4.90 \\
8.97 \\
11.34\end{array}$ & $\begin{array}{c}5.65 \\
9.24 \\
11.06 \\
\end{array}$ & $\begin{array}{l}6.11 \\
6.46 \\
6.85\end{array}$ & $\begin{array}{c}7.97 \\
9.55 \\
10.86\end{array}$ & $\begin{array}{l}8.40 \\
9.18 \\
9.95\end{array}$ & $\begin{array}{c}0.13 \\
5.94 \\
11.02\end{array}$ & $\begin{array}{c}9.10 \\
10.30 \\
10.90\end{array}$ & $\begin{array}{l}8.10 \\
8.20 \\
8.30\end{array}$ & $\begin{array}{c}9.00 \\
10.30 \\
11.30\end{array}$ \\
\hline $\begin{array}{l}\mathrm{BOC}_{5} \\
\left(\mathrm{mg} \mathrm{O}_{2} \cdot \mathrm{dm}^{-3}\right)\end{array}$ & $\begin{array}{l}1.50 \\
3.50 \\
6.60 \\
\end{array}$ & $\begin{array}{l}3.83 \\
6.39 \\
8.70\end{array}$ & $\begin{array}{l}3.55 \\
5.59 \\
7.58 \\
\end{array}$ & $\begin{array}{l}6.77 \\
6.85 \\
6.96 \\
\end{array}$ & $\begin{array}{l}4.40 \\
4.58 \\
4.68\end{array}$ & $\begin{array}{l}3.78 \\
5.31 \\
7.92 \\
\end{array}$ & $\begin{array}{l}3.47 \\
4.69 \\
5.86\end{array}$ & $\begin{array}{l}3.15 \\
5.81 \\
9.28\end{array}$ & $\begin{array}{l}4.70 \\
6.20 \\
7.70 \\
\end{array}$ & $\begin{array}{l}4.30 \\
5.45 \\
6.41\end{array}$ & $\begin{array}{l}4.90 \\
6.70 \\
8.70 \\
\end{array}$ \\
\hline $\begin{array}{l}\text { Biochemical oxygen } \\
\text { consump-tion }\left(\mathrm{BOC}_{5}\right) \\
\text { ratio on the dissolved } \\
\text { oxygen (DO) }(\%)\end{array}$ & $\begin{array}{l}31.01 \\
44.30 \\
59.90 \\
\end{array}$ & $\begin{array}{l}59.10 \\
73.02 \\
81.43 \\
\end{array}$ & $\begin{array}{l}37.84 \\
62.31 \\
76.83 \\
\end{array}$ & $\begin{array}{l}66.58 \\
74.13 \\
75.23 \\
\end{array}$ & $\begin{array}{l}61.50 \\
70.89 \\
77.13 \\
\end{array}$ & $\begin{array}{l}37.79 \\
55.60 \\
73.01 \\
\end{array}$ & $\begin{array}{l}35.97 \\
51.08 \\
62.50 \\
\end{array}$ & $\begin{array}{c}83.20 \\
97.81 \\
100 \\
\end{array}$ & $\begin{array}{c}44.10 \\
60.20 \\
85 \\
\end{array}$ & $\begin{array}{l}53.08 \\
66.46 \\
77.22 \\
\end{array}$ & $\begin{array}{l}39.70 \\
65.04 \\
73.00 \\
\end{array}$ \\
\hline $\begin{array}{l}\mathrm{COC} \\
\left(\mathrm{mg} \mathrm{O}_{2} \cdot \mathrm{dm}^{-3}\right)\end{array}$ & $\begin{array}{c}2.10 \\
7.10 \\
12.90 \\
\end{array}$ & $\begin{array}{l}21.83 \\
29.65 \\
33.00\end{array}$ & $\begin{array}{l}2.93 \\
4.26 \\
5.33\end{array}$ & $\begin{array}{l}7.10 \\
7.58 \\
8.23 \\
\end{array}$ & $\begin{array}{l}6.34 \\
7.07 \\
7.92 \\
\end{array}$ & $\begin{array}{l}5.11 \\
6.78 \\
8.40 \\
\end{array}$ & $\begin{array}{l}5.97 \\
6.80 \\
8.04 \\
\end{array}$ & $\begin{array}{c}4.88 \\
11.29 \\
17.41 \\
\end{array}$ & $\begin{array}{l}2.80 \\
4.30 \\
5.90\end{array}$ & $\begin{array}{l}2.40 \\
3.68 \\
4.63 \\
\end{array}$ & $\begin{array}{l}2.10 \\
3.50 \\
4.10\end{array}$ \\
\hline $\begin{array}{l}\text { Yearly biomass } \\
\text { average of the } \\
\text { phytoplankton } \\
\left(\mathrm{g} \cdot \mathrm{m}^{-3}\right)\end{array}$ & $\begin{array}{c}0.40 \\
69.23 \\
249.40\end{array}$ & $\begin{array}{c}0.60 \\
18.55 \\
63.12\end{array}$ & $\begin{array}{c}8.04 \\
\mathbf{5 1 . 2 9} \\
91.20\end{array}$ & $\begin{array}{c}17.05 \\
\mathbf{6 9 . 2 3} \\
101.59\end{array}$ & $\begin{array}{l}20.20 \\
34.60 \\
49.01\end{array}$ & $\begin{array}{c}5.63 \\
353.23 \\
806.33\end{array}$ & $\begin{array}{l}14.11 \\
28.56 \\
44.87\end{array}$ & $\begin{array}{c}1.70 \\
106.12 \\
228.97\end{array}$ & $\begin{array}{c}7.39 \\
42.98 \\
143.40\end{array}$ & $\begin{array}{c}8.67 \\
67.12 \\
108.90\end{array}$ & $\begin{array}{c}3.22 \\
49.53 \\
128.83\end{array}$ \\
\hline $\begin{array}{l}\text { Species ratio on the } \\
\text { phytoplankton } \\
\text { biomass } \\
(\%)\end{array}$ & $\begin{array}{c}1.23 \\
0.03 \\
0.67 \\
98.05 \\
-\end{array}$ & $\begin{array}{c}0.22 \\
20.34 \\
3.52 \\
95.53 \\
0.36\end{array}$ & $\begin{array}{c}42 \\
- \\
21 \\
24.30 \\
12.60\end{array}$ & $\begin{array}{c}23.22 \\
17.26 \\
24.58 \\
33.15 \\
1.77\end{array}$ & $\begin{array}{c}66.50 \\
2.50 \\
13.10 \\
1.30 \\
16.40\end{array}$ & $\begin{array}{c}9.62 \\
5.21 \\
8.66 \\
73.45 \\
3.03\end{array}$ & $\begin{array}{c}8.05 \\
4.02 \\
30.57 \\
55.23 \\
2.10\end{array}$ & $\begin{array}{c}9.75 \\
0.47 \\
25.98 \\
45.44 \\
18.33\end{array}$ & $\begin{array}{l}25.96 \\
47.95 \\
16.93 \\
2.25 \\
6.88\end{array}$ & $\begin{array}{c}33.96 \\
8.00 \\
28.23 \\
0.11 \\
29.67\end{array}$ & $\begin{array}{c}5.47 \\
60.89 \\
32.64 \\
- \\
0.98\end{array}$ \\
\hline $\begin{array}{l}\text { Number of the } \\
\text { phytoplankton } \\
\text { species }\end{array}$ & $\begin{array}{c}38 \\
19 \\
44 \\
18 \\
- \\
119 \\
\end{array}$ & $\begin{array}{c}35 \\
14 \\
38 \\
17 \\
2 \\
106 \\
\end{array}$ & $\begin{array}{c}11 \\
2 \\
24 \\
5 \\
6 \\
48 \\
\end{array}$ & $\begin{array}{c}21 \\
8 \\
38 \\
11 \\
12 \\
90\end{array}$ & $\begin{array}{c}- \\
1 \\
9 \\
2 \\
- \\
12 \\
\end{array}$ & $\begin{array}{c}5 \\
2 \\
20 \\
7 \\
1 \\
35 \\
\end{array}$ & $\begin{array}{c}31 \\
11 \\
48 \\
13 \\
2 \\
105 \\
\end{array}$ & $\begin{array}{c}13 \\
6 \\
19 \\
11 \\
3 \\
52 \\
\end{array}$ & $\begin{array}{c}22 \\
14 \\
37 \\
2 \\
6 \\
81 \\
\end{array}$ & $\begin{array}{c}25 \\
14 \\
41 \\
4 \\
11 \\
95 \\
\end{array}$ & $\begin{array}{c}26 \\
11 \\
37 \\
- \\
7 \\
81 \\
\end{array}$ \\
\hline $\begin{array}{l}\text { "a" chlorophyll } \\
\left(\mathrm{mg} \cdot \mathrm{m}^{-3}\right)\end{array}$ & $\begin{array}{c}3.50 \\
208.20 \\
1046.00\end{array}$ & $\begin{array}{c}2.10 \\
26.04 \\
74.58\end{array}$ & $\begin{array}{c}11.20 \\
35.90 \\
130.30 \\
\end{array}$ & $\begin{array}{c}6.30 \\
22.10 \\
36.30 \\
\end{array}$ & $\begin{array}{l}8.50 \\
9.20 \\
9.90 \\
\end{array}$ & $\begin{array}{c}5.96 \\
16.75 \\
47.81 \\
\end{array}$ & $\begin{array}{l}4.65 \\
6.31 \\
8.41\end{array}$ & $\begin{array}{l}79.79 \\
105.12 \\
130.21 \\
\end{array}$ & $\begin{array}{l}12.92 \\
34.94 \\
76.40 \\
\end{array}$ & $\begin{array}{l}14.87 \\
19.22 \\
23.22 \\
\end{array}$ & $\begin{array}{l}20.55 \\
23.59 \\
26.81\end{array}$ \\
\hline $\begin{array}{l}\text { Organic Carbon } \\
\left(\mathrm{mg} \cdot \mathrm{m}^{-3} \cdot \text { day }^{-1}\right)\end{array}$ & $\begin{array}{c}105 \\
6241.60 \\
31358.0 \\
\end{array}$ & $\begin{array}{c}63 \\
779.18 \\
2230.60 \\
\end{array}$ & $\begin{array}{c}335 \\
1073.00 \\
3896.00 \\
\end{array}$ & $\begin{array}{c}188 \\
658.00 \\
1078.00 \\
\end{array}$ & $\begin{array}{l}120.92 \\
590.12 \\
889.43 \\
\end{array}$ & $\begin{array}{c}178.70 \\
500.94 \\
1429.50 \\
\end{array}$ & $\begin{array}{l}138.98 \\
188.98 \\
251.59\end{array}$ & $\begin{array}{l}2234.11 \\
2998.12 \\
3671.81 \\
\end{array}$ & $\begin{array}{c}386.00 \\
1044.00 \\
2284.00\end{array}$ & $\begin{array}{c}445 \\
574.00 \\
694.00 \\
\end{array}$ & $\begin{array}{c}614 \\
705.00 \\
801.00 \\
\end{array}$ \\
\hline $\begin{array}{l}\text { Yearly average } \\
\text { biomass of } \\
\text { zooplankton }\left(\mathrm{mg}^{3} \mathrm{~m}^{3}\right)\end{array}$ & $\begin{array}{l}150.30 \\
346.27 \\
706.92\end{array}$ & $\begin{array}{c}91.03 \\
626.42 \\
1720.13\end{array}$ & $\begin{array}{l}188.94 \\
313.03 \\
464.05\end{array}$ & $\begin{array}{l}157.61 \\
282.73 \\
369.53\end{array}$ & $\begin{array}{l}4.75 \\
7.21 \\
9.65\end{array}$ & $\begin{array}{c}47.98 \\
392.83 \\
1333.48\end{array}$ & $\begin{array}{l}59.86 \\
308.15 \\
648.14\end{array}$ & $\begin{array}{l}1837.23 \\
9028.2 \\
49317\end{array}$ & $\begin{array}{l}71.98 \\
\mathbf{6 2 2 . 9 2} \\
1981.9\end{array}$ & $\begin{array}{l}32.02 \\
78.76 \\
121.64\end{array}$ & $\begin{array}{l}26.92 \\
35.57 \\
40.45\end{array}$ \\
\hline $\begin{array}{l}\text { Species ratio on the } \\
\text { zooplankton biomass } \\
(\%)\end{array}$ & $\begin{array}{c}36.98 \\
0.61 \\
12.05 \\
50.33 \\
\end{array}$ & $\begin{array}{l}11.42 \\
0.02 \\
2.41 \\
86.13 \\
\end{array}$ & $\begin{array}{c}31 \\
- \\
91.4 \\
5.5 \\
\end{array}$ & $\begin{array}{c}7.13 \\
0.01 \\
76.55 \\
16.31 \\
\end{array}$ & $\begin{array}{c}21.6 \\
0.7 \\
48.9 \\
28.8 \\
\end{array}$ & $\begin{array}{c}1.46 \\
41.86 \\
37.71 \\
18.95 \\
\end{array}$ & $\begin{array}{c}2.07 \\
0.04 \\
68.51 \\
29.37 \\
\end{array}$ & $\begin{array}{c}11.93 \\
- \\
52.20 \\
35.85 \\
\end{array}$ & $\begin{array}{c}3.08 \\
0.01 \\
95.65 \\
1.25 \\
\end{array}$ & $\begin{array}{c}13.97 \\
0.03 \\
62.59 \\
23.38 \\
\end{array}$ & $\begin{array}{c}41.43 \\
0.05 \\
45.17 \\
13.32 \\
\end{array}$ \\
\hline $\begin{array}{l}\text { Number of the } \\
\text { zooplankton species }\end{array}$ & - & $\begin{array}{c}12 \\
2 \\
5 \\
7 \\
27\end{array}$ & $\begin{array}{l}5 \\
5 \\
7 \\
7 \\
19\end{array}$ & - & - & $\begin{array}{c}18 \\
1 \\
10 \\
15 \\
\mathbf{4 4} \\
\end{array}$ & $\begin{array}{c}16 \\
1 \\
10 \\
8 \\
35 \\
\end{array}$ & $\begin{array}{c}11 \\
- \\
9 \\
5 \\
25 \\
\end{array}$ & $\begin{array}{c}8 \\
- \\
7 \\
11 \\
26\end{array}$ & $\begin{array}{c}9 \\
1 \\
3 \\
5 \\
18 \\
\end{array}$ & $\begin{array}{c}7 \\
- \\
4 \\
1 \\
12 \\
\end{array}$ \\
\hline
\end{tabular}




\section{Conclusions}

The following conclusions can be drawn from the research carried out in the 9 lakes that were examined:

1. The general state of the lakes that were studied is extremely different: there are lakes with reduced anthropic influence (Limanu, Valea Arsa and Hagieni), all of them situated in the southern part of the Romanian sea coast, which are the cleanest; they are followed by the big lakes in the northern part of the sea coast (Razim and Sinoe), which are fed, directly or indirectly, with water from the Danube River. The other lakes, being situated in agricultural or suburban areas, evolve more rapidly towards eutrophication. The lake which is in the most advanced stage of eutrophication is the Tabacarie Lake, as it has been under the influence of the discharges of waste waters from the municipality of Constanta for many years.

2. The organic load of the waters of the sea coast lakes is relatively high: the mean value of the COD is approximately $5.77 \mathrm{mgO}_{2} / \mathrm{dmc}$, which places the waters in the second category after the Romanian standards of quality. The fluctuations from one lake to another are relatively reduced.

3 . Most of the primary plankton production is achieved, as a rule, in the first $50 \mathrm{~cm}$ of the mass of water from the surface (in the euphotic area), where the transparency is also optimum and where the values of chlorophyll "a" are maximum.

4. The mean transparency of the waters of the lakes is $30-40 \mathrm{~cm}$, with maximum fluctuations between 19 and $112 \mathrm{~cm}$, but which varies from one lake to the other (the highest fluctuations are usually recorded in the cleanest lakes).

5. There is a poor correlation between the quantities of chlorophyll "a" and the mean biomass of the phytoplankton, but there is a good correlation between the quantity of chlorophyll "a" and the quantity of organic carbon in the waters of the lakes.

6. The data indicate that the most eutrophicated lakes are Tabacarie and Tasaul. The values of the parameters analyzed in the Razim Lake are contradictory along the study period, in terms of the values ranges, as they indicate the existence of an intense process of eutrophication here as well.

7. We believe that the data presented in Table 1 are significant as they show the real situation of these lakes in the last decade. At the same time we can estimate that during the past years the anthropic pressure has decreased which leads us to consider that the anthropic contribution to the eutrophication process has been reduced, but it still persists at dangerous high values.

8. Based on the studies undertaken during the last decade concerning the lakes on the Romanian Black Sea coast it is imperious to take urgent steps, specific for every lake, to efficiently fight against the process of eutrophication and organic silting in order to achieve systems for the retention of rainfall waters and polluted waters and the extraction of the nutrients which might reach the lakes.

\section{Acknowledgements}

We would like to express our gratitude for the support received from our colleagues from the Ovidius University of Constanta, from the Danube Delta National Institute for Research and Development in Tulcea and from the Institute of Applied Ecology in Bucharest who have graciously placed at our disposal the results of the sectorial tests they had performed. Without these, our synthesis would not have been possible.

\section{References}

Breier A. 1977 - Evoluţia lacurilor de pe litoralul românesc al Mării Negre - studiu hidrogeografic. Hydrobiologia, 15, 29-36.

Chirilă E., Birghilă A.S. \& Godeanu S.1998 - Analytical characterization of seacoast lake waters. Analele Univ. "Ovidius" Constanţa, ser. Inginerie (Chimie), 48-50.

Chirilă E., Birghilă A.S., Capotă A.P., Godeanu S. \& Galațchi L. D. 1999 - Contribution on the Analytical Characterization of the Black Sea Coast Lakes. Environ. Manage., 2: 205-212.

David C. \& Despina C. 1997 - Nutrienţii în Rezervaţia Bisferei Delta Dunării 1991-1995. Analele Şt. Inst. Cercet. Proiect., „Delta Dunării" Tulcea, V, 2, 31-36.

Florescu M., Ghinea M. \& Chirea R. 1982 - Evoluţia indicilor de troficitate ai lacului Siutghiol ca urmare a sistării unor surse de impurificare. Pontus Euxinus - Studii şi Cercetări, II, 294-296.

Galaţchi L. 1997 - Productivitatea primară în lacul paramarin Tăbăcărie. Analele St. Inst. Cercet. Proiect. „Delta Dunării” Tulcea, V, 1, 189-194.

Godeanu S.P. 1994 - Caracteristicile ecologice ale bazinelor acvatice hipereutrofe. Ecologie şi Protecţia Mediului Constanţa, X, $72-78$.

Petran A. 1998 - The Biological Diversity of Lake Sinoe. The Black Sea Diversity - Romania. U.N. Black Sea Environmental Series, New York, 4, 103-114.

Popa M., Roban A., Iliescu M. 1996 - Ėvolution de la biodiversitè du phytoplancton de la lagune Sinoe pendant la période 1970 - 1995 Cercetări Marine - IRCM. Constanţa, 29, 437-456.

Roban A. 1988 - Dynamique qualitative et quantitative de la microflore planctonique des eaux du lac Sinoe pendant la période 19711980. Cercetări Marine - IRCM, Constanţa, 20/21, 251-273. 